\title{
Diskursus Khilafah dalam Kajian Fiqh Siyasah Klasik dan Kontemporer
}

\author{
Ismail Marzuki \\ Universitas Islam Negeri Walisongo Semarang \\ Jl. Walisongo No.3-5, Tambakaji, Kec. Ngaliyan, Semarang, Jawa Tengah \\ Email:ismail_marzuki@walisongo.ac.id
}

\begin{tabular}{llll} 
Submit & $: 20$ September 2020 & Diterima & $: 22$ Februari 2021 \\
Revisi & $: 26$ Oktober 2021 & Terbit & $: 1$ Desember 2021 \\
\hline
\end{tabular}

\begin{abstract}
Until now, the Muslim community in Indonesia is flooded with massive information about the discourse of the obligation to establish a caliphate. Some argue that establishing a caliphate is an obligation for all Muslims. This article discusses the caliphate discourse in the study of figh siyasa in the classical era and the contemporary era. The discourse on the caliphate in the contemporary era has warmed up after the collapse of the Ottoman Turks in 1924, the debate on the theme of the caliphate in the contemporary era is about whether there is a standard form of government and Islam, the legal status of establishing a caliphate, and so on. This theme is different from the themes of the discussion of the caliphate in the classical era, in this era the themes of the caliphate revolved around aspects of Islamic leadership values, such as procedures for choosing a caliph / leader, political ethics that must be held by leaders and other state officials.
\end{abstract}

Keywords: Discourse, fiqh siyasa, classic, contemporary, Islamic politics

Abstrak: Hingga kini, masyarakat muslim di Indonesia dibanjiri informasi yang sangat masif tentang wacana kewajiban mendirikan khilafah. Sebagian berpendapat bahwa mendirikan khilafah merupakan satu kewajiban seluruh ummat Islam. Artikel ini mendiskusikan dikursus khilafah dalam kajian fiqh siyasah era klasik dan era kontemporer. Dikursus khilafah di era kontemporer menghangat pasca runtuhnya Turki Utsmani pada tahun 1924, perdebatan dalam tema khilafah di era kontemporer seputar apakah ada bentuk baku pemerintahan dan Islam, status hukum mendirikan khilafah, dan sebagainya. Tema ini berbeda dengan tema-tema pembahasan khilafah pada era klasik, pada era ini tema-tema tentang khilafah berputar pada aspek nilai-nilai kepemimpinan, seperti tata cara memilih khalifah / pemimpin, etika politik yang harus dipegang oleh para pemimpin dan para pejabat negara lainnya.

Kata kunci: Diskursus, fiqh siyasah, klasik, kontemporer, politik Islam

\section{Pendahuluan}

Pasca reformasi, publik di Indonesia dibanjiri informasi yang sangat masif tentang wacana kewajiban mendirikan khilafah. Salah satu kelompok yang gencar melakukan gerakan serta mengkampanyekan gagasan khilafah adalah Hizbut Tahrir Indonesia (HTI). Menurut HT, mendirikan khilafah merupakan satu kewajiban seluruh ummat Islam. Selama khilafah belum berdiri, maka setiap 
individu muslim yang mukallaf memiliki kewajiban untuk menegakkan khilafah tanpa pandang bulu. Bahkan, dalam pandangan Taqi al-din al-nabhani (pendiri HT) seorang muslim yang berdiam diri atau tidak turut serta berusaha mengangkat seorang khalifah merupakan suatu perbuatan dosa yang sangat besar, karena dinilai mengabaikan salah satu kewajiban yang sangat penting dalam islam. ${ }^{1}$

Massifnya informasi (baca: propaganda) tentang kewajiban mendirikan khilafah yang dilakukan oleh HT di Indonesia dikarenakan Indonesia merupakan salah satu sasaran penting tegaknya khilafah. Hal ini dibuktikan dengan digelarnya konferensi khilafah internasional pertama pada 28 Mei tahun 2000 dan konferensi kedua pada 12 Agustus tahun 2007. Pada tahun 2011, Ismail Yusanto (seorang tokoh dan juru bicara HTI) menjelaskan lima alasan peluang besar bagi tegaknya khilafah di Indonesia, yaitu: 1) dukungan ummat islam yang besar, 2) HTI semakin besar dan dakwah berjalan dengan aman, 3) kepercayaan publik terhadap pemerintah Indonesia semakin merosot, 4) besarnya potensi SDA dan SDM di Indonesia, 5) pengalaman historis Indonesia dalam menerapkan syariat islam. $^{2}$

Propaganda tentang gagasah khilafah yang dilakukan oleh HTI sangat massif, dan hasilnya cukup menakjubkan. Hal ini dapat dilihat dari rapat-rapat besar yang dilakukan oleh organisasi HTI dalam rangka merebut diskursus di ruang publik tentang gagasan khilafah yang mereka usung. Tidak tanggung-tanggung, beberapa kali rapat dalam sekala besar yang mereka selenggarakan diikuti oleh puluhan ribu orang anggota HTI dari seluruh pelosok Indonesia.

Gagasan mengenai khilafah sebetulnya tidak hanya diusung HT, termasuk HT di Indonesia. Pada tingkat tertentu gerakan tarbiyyah yang condong ke Ikhwanul Muslimun, juga mencita-citakan negara Islam, meski namanya bukan khilafah. Mereka sama-sama mendambakan pemerintahan yang merujuk Al-Quran dan Sunnah. Bedanya, gerakan tarbiyah percaya pada demokrasi sebagai jalan untuk menegakkan negara Islam. Sementara itu, HT menolak mentah-mentah. Bagi mereka demokrasi adalah produk Barat, titik. ${ }^{3}$

Selain kedua gerakan tersebut, Negara Islam Irak dan Suriah (ISIS) malah sudah mendeklarasikan Abu Bakr al-Baghdadi sebagai khalifah. Mereka mengklaim negara khilafah telah ditegakkan di Syiria. Sejumlah hukum Islam telah mereka terapkan. Perempuan yang keluar rumah dengan pakaian selain warna hitam dihukum mati. Orang yang diduga LGBT dilempar dari atap gedung. Tentara musuh dibakar hidup-hidup. Diakui atau tidak, semua keputusan tersebut dilakukan merujuk dalil dalam Al-Qur'an dan atau Hadits. ${ }^{4}$

Karena dianggap bertentang dengan ideologi dan hukum negara, maka pemerintah--Melalui Kemenkumham--pada akhirnya secara resmi membubarkan HTI pada 19 juli 2017. Kemenkumham mencabut status badan hukum HTI berdasarkan SK Menteri Hukum dan HAM nomor AHU-30.AH..01.08 tahun 2017 tentang pencabutan keputusan menteri hukum dan HAM nomor AHU-0028.60.10.2014 tentang pengesahan pendirian badan hukum perkumpulan HTI. ${ }^{5}$ Sejalan dengan pemerintah, Jendral TNI (Purn) Agum Gumelar berpendapat bahwa ideologi khilafah lebih berbahaya dari marxisme-

1 Ainur Rofiq al-Amin, Membongkar Proyek Khilafah Ala Hizbut Tahrir Indonesia (Yogyayakarta: LKiS, 2012), $105,107$.

2 Joko Prasetyo, "Gagasan Khilafah sampai di Bumi Sakura", dalam Media Umat, edisi 56 (April 2011), 14. Lihat pada Ainur Rofiq al-Amin, Membongkar Proyek Khilafah, 5-6.

3 Husni Mubarok, “Ide Khilafah, ujian kita berdemokrasi”, https:/geotimes.co.id/kolom/ide-khilafah-ujian-kita-berdemokrasi/. Diakses pada 17 September 2020.

4 Husni Mubarok, “Ide Khilafah, ujian kita berdemokrasi”, https:/geotimes.co.id/kolom/ide-khilafah-ujian-kita-berdemokrasi/. Diakses pada 17 September 2020.

5 “HTI resmi dibubarkan pemerintah" Kompas.com 19/07/2017/pukul 10.18 WIB. 
komunisme karena gerakanya sangat rapi dan sangat sistematis. Keberadaan ide tentang khilafah menjadi ancaman yang sangat serius bagi keberlangsungan ideologi Pancasila. ${ }^{6}$

Pembubaran HTI merupakan pukulan telak bagi kelompok-kelompok pengusung khilafah, dan pembubaran organisasi HTI merupakan sesuatu yang wajar, karena gagasan sistem khilafah yang diusungnya bertentangan dengan konsep negara bangsa seperti NKRI. Meskipun HTI telah dibubarkan oleh pemerintah, ternyata gagasan khilafah masih tetap hidup, tetap disebarkan meski secara terselubung.

Jika kita melihat pendapat para ulama yang otoritatif di bidang fiqh siyasah, kita akan menemukan informasi yang berbeda dengan pendapat disampaiakan oleh kalangan pengusung gagasan khilafah di Indonesia yang menyatakan bahwa mendirikan khilafah adalah kewajiban agama islam.

Jika dilihat dalam ragam aliran pemikiran di dalam fiqh siyasah kontemporer, gagasan tentang kewajiban mendirikan khilafah (baca: khilafah islamiyah) diusung oleh aliran integralistik, hal ini merupakan konsekuensi logis dari konsep aliran ini yang menyatukan agama dan negara dan negara. Aliran sekularistik, dan aliran simbiotik memiliki pandangan bahwa agama dan negara tidak dijadikan satu sebagaimana konsep pemikiran aliran integralistik, konsekuensinya adalah aliran sekularistik dan simbiotik menolak konsep khilafah islamiyah. ${ }^{7}$

Dari uraian di atas, dapat diketahui bahwa ulama berbeda pendapat tentang gagasan khilafah islamiyah. Pendapat bahwa mendirikan khilafah merupakan kewajiban agama islam yang sudah menjadi ijma' di kalangan ulama merupakan klaim kebenaran yang bersifat sepihak dari HTI dan organasasi-organisasi pengusung khilafah di Indonesia. Oleh sebab itu perlu ada penelitian lebih lanjut tentang bagaimana sesungguhnya diskursus khilafah dalam kajian fiqh siyasah klasik dan kontemporer. Hal ini penting untuk dilakukan karena gagasan khilafah secara pelan tapi pasti dapat menggerogoti eksistensi negara Indonesia.

Dari uraian latar belakang masalah tersebut di atas, selanjutnya dirumuskan dua rumusan masalah sebagai berikut: (a) Bagaimana diskursus khilafah dalam kajian fiqh siyasah klasik? (b) Bagaimana diskursus khilafah dalam kajian fiqh siyasah kontemporer?

\section{Khilafah dalam Kajian Fiqh Siyasah Klasik}

Menurut Prof. Quraisy Syihab -sebagimana telah disarikan oleh redaktur NU Online- Khilafah dan Khalifah merupakan kata yang berasal dari kata Khalaf yang berarti di belakang. Maknanya adalah sesuatu atau seseorang yang datang di belakang orang lain atau sesudah orang lain. Dalam Al-Qur'an kata ini memiliki dua kata jamak, yakni Khulafa dan Khalaif. Kata Khulafa berarti pemimpin dalam penegakan hukum dan Khalaif berarti pemelihara yang mengantarkan segala sesuatu kepada tujuan penciptaannya. Al-Qur'an menggunakan kata Khalifah untuk dua makna. Pertama, yakni ketika Allah hendak menciptakan manusia yang termaktub dalam Q.S. Al-Baqarah: 30, sebagai berikut:

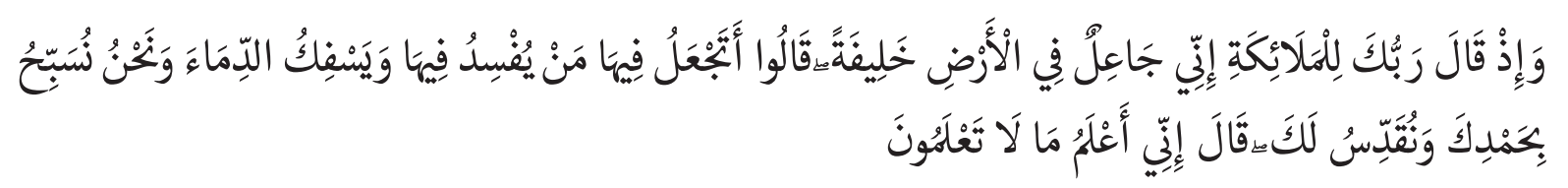

6 "Agum Gumelar: khilafah lebih berbahaya daripada komunisme" jurnal intelijen.net. 05 Agustus 2019.

7 Mujar Ibnu Syarif dan Khamami Zada, Fiqh Siyasah: Doktrin Dan Pemikiran Politik Islam (Jakarta: Penerbit Erlangga, 2008 ), 39-42. 
Artinya: "Ingatlah ketika Tuhanmu berfirman kepada para Malaikat: "Sesungguhnya Aku hendak menjadikan seorang khalifah di muka bumi".

Yang dimaksud dengan khalifah di sini adalah manusia, yakni Nabi Adam AS sehingga manusia adalah Khalifah. Posisi manusia sebagai khalifah menuntutnya untuk memelihara dan menghantarkan segala yang berwujud di dunia ini kepada fungsi dan tujuan penciptaannya. Laut, misalnya, diciptakan sebagai tempat berlayar kapal untuk mencari ikan-ikan, mutiara dan sebagainya. ${ }^{8}$

Penggunaan kata khalifah yang kedua yakni ketika Nabi Daud diangkat sebagai penguasa yang termaktub dalam QS Shad: 26, yang berbunyi sebagai berikut:

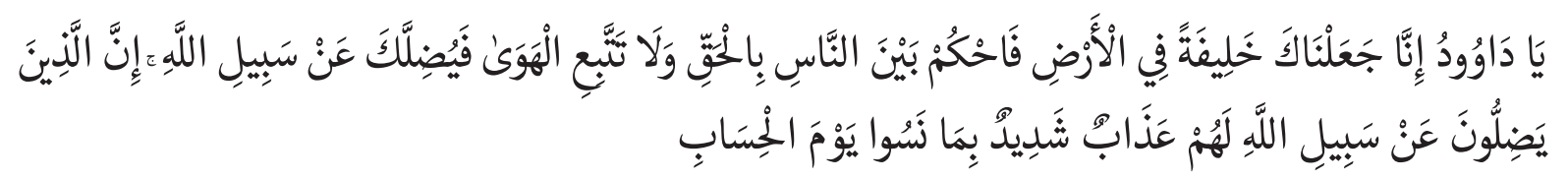

Artinya: "Wahai Daud! Sesungguhnya engkau Kami (Allah) jadikan khalifah (penguasa) di bumi, maka berikanlah keputusan (perkara) di antara manusia dengan adil dan janganlah engkau mengikuti hawa nafsu, kerena akan menyesatkan engkau dari jalan Allah. Sungguh, orang-orang yang sesat dari jalan Allah akan mendapat azab yang berat, karena mereka melupakan hari perhitungan".

Khalifah yang dimaksud dalam hal ini adalah "penguasa” yang memiliki kekuasaan politik untuk mengatur masyarakat. Dan dalam konteks ini, tidak semua manusia bisa menjadi khalifah. Dalam kontek kehidupan berbangsa dan bernegara, tidak semua individu wajib dan berhak menegakkan hukum sendiri-sendiri. Kekhalifahan dalam konteks ini bisa disamakan dengan sistem pemerintahan. ${ }^{9}$

Sistem pemerintahan yang dipraktekan dalam dunia Islam selama rentang yang sangat panjang, mulai abad ke-7 masehi bermacam-macam, yaitu: sistem khilafah, sistem pemerintahan imamah, monarki, dan demokrasi. Terdapat dua jenis sistem khilafah, khilafah berdasarkan syura (musyawarah), dan khilafah dengan corak monarki. ${ }^{10}$

Persoalan besar pertama yang muncul setelah Nabi Muhammad SAW wafat pada tahun $632 \mathrm{M}$ / $10 \mathrm{H}$ adalah penggantian beliau selaku pemimpin. Semasa hidupnya, Nabi Muhammad SAW memang tidak pernah menunjuk siapa yang akan menggantikan kepemimpinan baliau kelak. Di samping itu, Nabi Muhammad SAW juga tidak memberi petunjuk tentang tatacara pengangkatan pemimpin yang menjadi penggantinya (khalifah). Ketidak adaanya petunjuk tersebut menimbulkan permasalahan di kalangan ummat Islam setelah Nabi SAW wafat, sehingga hamper saja terjadi perpecahan antara kaum muhajirin dan kaum anshor. ${ }^{11}$

Sehari setelah wafatnya Nabi Muhammad SAW, kaum anshor memprakarsai musyawarah besar di Tsaqifah bani Sa'idah. Mereka sibuk membicarakan siapa yang akan diangkat menjadi khalifah pengganti kekuasaan politik Nabi Muhammad SAW. Dalam pertemua tersebut suku Khazraj menunjuk Sa'ad bin Ubadah sebagai khalifah, namun suku Aws belum bersedia menerima pencalonan Sa'ad tersebut, karena mereka juga mempertimbangkan kemungkinan golongan muhajirin menentukan calonnya sendiri. menghadapi keberatan suku aws, sebagian suku Khazraj bersikukub pada pendirian

\footnotetext{
8 “Menengok Kembali Makna Khilafah dan Khalifah", Rabu 3 April 2019 10:30 WIB https://www.nu.or.id/post/read/104352/ menengok-kembali-makna-khilafah-dan-khalifah diakses pada 13 /08/2019.

9 "Menengok Kembali Makna Khilafah dan Khalifah", Rabu 3 April 2019 10:30 WIB https://www.nu.or.id/post/read/104352/ menengok-kembali-makna-khilafah-dan-khalifah diakses pada 13/08/2019.

10 Mujar Ibnu Syarif dan Khamami Zada, Figh Siyasah: Doktrin dan Pemikiran, 204.

${ }_{11}$ Muhammad Iqbal, Fiqh Siyasah: Kontekstualisasi Doktrin Politik Islam, 50.
} 
mereka, meskipun kaum muhajirin jug akan mempertahankan pemimpin dari kalangan mereka. Sekelompok suku aws tersbut berkata "kalua demikian, kita akan katakana kepada mereka (kaum muhajirin) bahwa dari kita seorang amir dan dari mereka seorang amir. Selain itu, kita tidak akan setuju". Menanggapi pendapat demikian, Sa'ad bin Ubadah menyatakan bahwa ini akan menjadi awal kelemahan yang akan membawa kepada perpecahan ummat Islam. ${ }^{12}$

Padapagi hariitu,Umarbin Khattab mendengarberita bahwa kelompokansor sedang mengadakan pertemuan di Tsaqifah bani Sa'idah untuk mengangkat pemimpin. Dalam keadaan gusar, Umar bin Khattab pergi ke kediaman Nabi Muhammad SAW untuk memanggil Abu Bakar yang berada dalam rumah dan memintanya untuk keluar. Semula Abu Bakar menolak karena sedang sibuk mengurusi jenazah Nabi Muhammad SAW. Tetapi pada akhirnya Abu Bakar berkenan keluar menemui Umar bin Khattan setelah dijelaskan bahwa ada satu pertemuan penting yang mengharuskan kehadiran Abu Bakar. Kemudian Abu Bakar Bersama Umar bin Khattab dan Abu 'Ubaidah bin Jarrah bergegas pergi menuju Tsaqifah bani Sa'idah. ${ }^{13}$

Ketika Abu Bakar, Umar bin Khattab, dan Abu 'Ubadah bin Jarrah tiba di Tsaqifah bani Sa'idah, kaum anshor masih terlibat diskusi yang alot. Merekapun mecapai kata sepakat tentang persoalan Sa'ad ibnu 'Ubadah. Melihat kedatangan tiga orang tersebut, semua hadirin berhenti berbicara, sebenarnya Umar bin Khattab ingin berbicara lebih dulu kepada kaum anshor tetapi dicegah oleh Abu Bakar, karena khawatir jika sikap Umar yang keras akan menimbulkan gejolak di kalangan ansor dan perpecahan di tubuh ummat Islam, apalagi situasinya sedang panas dan alot. Akhirnya Abu Bakar berbicara terlebih dahulu. Pembicaraan Abu Bakar ternyata juga menimbulkan reaksi di kalangan anshor, mereka menolak kepemimpinan berada di tangan Muhajirin, sebagaimana usulan Abu Bakar "nahnu al-umara, wa antum al-wuzara' (kami menjadi pemimpinnya, dan kalian menjadi wazirnya)". ${ }^{14}$

Masing-masing pihak mengungkapkan argumentasinya terkait hak mereka menjadi pemimpin. Pihak anshor menganggap mereka lebih berhak karena mereka menampung Nabi SAW dan kaum muhajirin ketika dakwah Nabi SAW dan kaum muhajirin dimusuhi oleh kafir Mekkah. Sementara, kelompok muhajirin juga merasa lebih berhak karena merekalah yang berjuang Bersama Nabi Muhammad SAW dan mengalami pahit getirnya perjuangan tegaknya agama Islam semenjak di Makkah. ${ }^{15}$

Abu Bakar denngan nada tenang mengingatkan kepada kelompok anshor bukankah Nabi SAW pernah bersabda bahwa kepemimpinan umat islam seyogyanya berada pada suku Quraisy, dan bahwa hanya di bawah pimpinan suku Quraisy itulah terjamin keutuhan, keselamatan, dan kesejahteraan bangsa Arab. Abu Bakar juga mengingatkan orang-orang anshor tentang masalah mereka sebelum masuk Islam. Bukankah suku Aws dan Khazraj selalu bermusuhan, dan kalua nanti yang menjadi khalifah adalah orang anshor dari dua suku utama tersebut, maka besar kemungkinan suku yang lain tidak menerimanya, yang berakibat kambuhnya kembali permusuhan zaman jahiliyah. Kemudian Abu Bakar menawarkan dua tokoh Quraisy untuk dipilih sebagai pemimpin, yaitu Umar bin Khattab dan Abu 'Ubaidah bin Jarah. ${ }^{16}$

Orang-orang anshor tampaknya sangat terkesan oleh ucapan Abu Bakar tersebut. Melihat

\footnotetext{
12 Muhammad Iqbal, Fiqh Siyasah: Kontekstualisasi Doktrin Politik Islam, 50-51.

13 Munawir Sjadzali, Islam dan Tata Negara: Ajaran, Sejarah, dan Pemikiran, 22.

${ }_{14}$ Muhammad Iqbal, Fiqh Siyasah: Kontekstualisasi Doktrin Politik Islam, 51-52.

${ }_{15}$ Muhammad Iqbal, Fiqh Siyasah: Kontekstualisasi Doktrin Politik Islam, 52.

${ }^{16}$ Munawir Sjadzali, Islam dan Tata Negara: Ajaran, Sejarah, dan Pemikiran, 22.
} 
momentum yang sangat baik tersebut, Umar tidak menyia-nyiakannya, Umar bangun dari tempat duduknya dan menuju tempat Abu Bakar untuk berbai'at dan menyatakan kesetiaannya kepada Abu Bakar sebagai khalifah, seraya menyatakan bahwa bukankah Abu Bakar yang selalu diminta oleh Nabi SAW sebagai imam shalat bilamana Nabi SAW sakit, dan bahwa Abu Bakar adalah sahabat yang paling disayangi oleh Nabi Muhammad SAW. Gerakan Umar tersebut kemudian diikuti oleh Abu 'U baidah bin Jarrah. Sebelum dua tokoh Quraisy tersebut tiba di depan Abu Bakar dan mengucapkan bai'at, Basyir bin Sa'ad seorang tokoh anshor dan suku khazraj, mendahului mengucapkan bai'atnya kepada Abu Bakar, setelah itu diikuti Umar bin Khattab, Abu 'Ubaidah bin Jarrah dan para sahabat yang hadir, baik dari kalangan muhajirin dan anshor, termasuk tokoh ansor dari suku Aws yaitu Asid bin Khudair. ${ }^{17}$ Sementara tokoh dari suku Khazraj yang sebelumnya menjadi kandidat yang dicalonkan menjadi khalifah, yaitu Sa'ad bin 'Ubadah sampai akhir kepemimpinan Abu Bakar, tidak pernah memberikan bai'at kepada Abu Bakar sebagai khalifah. ${ }^{18}$

Pada tahun ketiga kepemimpinan Abu Bakar, Abu Bakar mendadak jatuh sakit. Selama empat belas hari, dia tidak bisa memimpin sholat berjama'ah di masjid. Sebagai wakil, Abu Bakar menunjuk 'Umar bin Khattab menjadi imam sholat. Setelah merasa sakitnya semakin parah dan sudah dekat dengan ajal, Abu Bakar merasa perlu memberikan wasiat tentang penggantinya kelak. Abu Bakar menetapkan Umar bin Khattab sebagai khalifah. Dalam penetapan tersebut, Abu Bakar melakukan musyawarah (konsultasi) dengan para sahabat lainya, di antaranya adalah Abdurrahman bin Awf, 'Usman bin Affan, Asid bin Khudaid. ${ }^{19}$

Setelah bermusyawarah dengan tiga tokoh sahabat tersebut, Abu Bakar meminta 'Usman untuk menuliskan pesan tentang penunjukan 'Umar sebagai penggantinya. Belum selesai mendiktekan wasiat tersebut, tiba-tiba Abu Bakar pingsan. 'Usman yang sudah mengerti maksud dari wasiat yang akan disampaikan Abu Bakar tersebut terus saja melanjutkan menulis wasiat. Setelah Abu Bakar siuman, Abu Bakar meminta 'Usman membacakan isi wasiat yang telah dia tulis. Mendengar apa yang dibaca 'Usman telah sesuai dengan pesannya, Abu Bakar puas dan bertakbir serta berterimakasih kepada 'Usman. ${ }^{20}$

Abu Bakar lalu menemui ummat Islam yang berkumpul di masjid dan menyampaikan keputusannya memilih 'Umar bin Khattab. Abu Bakar bertanya "Apakah kalian semua rela menerima orang yang kelak memimpin kamu? Demi Allah, sesungguhnya aku kelak tidak akan melupakan pemikiranku dan tidak memilih kerabatku sebagai penggantiku untuk memimpin kamu, aku mengangkat 'Umar. Karena itu, dengar dan patuhilah dia." Para hadirinpun menyatakan sikap setuju dan mematuhi apa yang disampaikan oleh Abu Bakar. ${ }^{21}$

Dalam masalah suksesi kepemimpinan, 'Umar menempuh jalan yang berbeda dengan pendahulunya. Setelah mengalami luka parah akibat penusukan yang dilakukan oleh budak Persia bernama Abu Lu'luah. Para sahabat pada saat itu khawatir jikalau 'Umar meninggal dunia dan tidak sempat meninggalkan pesan tentang penggantinya. Hal ini bisa membahayakan ummat Islam, mengingat trauma peristiwa di Tsaqifah Bani Sa'idah belum hilang dari ummat Islam. Semula 'Umar

\footnotetext{
$\overline{17}$ Munawir Sjadzali, Islam dan Tata Negara: Ajaran, Sejarah, dan Pemikiran, 22-23.

18 Muhammad Iqbal, Figh Siyasah: Kontekstualisasi Doktrin Politik Islam, 52.

${ }^{19}$ Muhammad Iqbal, Fiqh Siyasah: Kontekstualisasi Doktrin Politik Islam, 61-62.

${ }^{20}$ Muhammad Iqbal, Figh Siyasah: Kontekstualisasi Doktrin Politik Islam, 62.

${ }^{21}$ Muhammad Iqbal, Fiqh Siyasah: Kontekstualisasi Doktrin Politik Islam, 62.
} 
menolak sulan para sahabat tersebut. Menurutnya orang yang pantas untuk menduduki jabatan puncak menggantikannya sudah lebih dahulu meninggal. ${ }^{22}$

Bahkan, 'Umar marah besar Ketika para tokoh dari kalangan sahabat tersebut mengusulkan agar 'Umar menunjuk putranya Abdullah bin 'Umar sebagai penggantinya, 'Umar menolak keras usulan tersebut seraya mengatakan bahwa cukuplah sudah seorang dari keluarga 'Umar yang mendapatkan kehormatan untuk menjadi khalifah. Akhirnya, para tokoh sahabat tersebut dengan kecewa meninggalkan rumah kediaman 'Umar. Akan tetapi, karena bahaya perpecahan ummat Islam semakin tampak, mereka Kembali lagi mengunjungi ‘Umar dan mendesaknya agar segera menunjuk penggantinya. ${ }^{23}$

Pada akhirnya 'Umar tikak bisa mengelak dari permintaan tersebut, akan tetapi 'Umar tidak menunjuk secara langsung siapa penggantinya. 'Umar hanya menunjuk enam sahabat senior, dan merekalah nanti sepeninggalnya yang harus memilih seorang di antara mereka menjadi khalifah. Enam orangtersebut adalah 'Utsman bin Affan, Ali bin Abi Thalib, Sa'ad bin Abi Waqqash, Abdurrahman bin Awf, Zubair bin Awwam, dan Thalhah bin Ubaidillah, serta Abdullah bin 'Umar tetapi "tanpa memiliki hak suara”. Menurut 'Umar, dasar pertimbangan mengapa memilih enam orang tersebut -yang semuanya merupakan kaum muhajirin atau suku Quraisy- adalah karena mereka berenam itu dahulu dinyatakan oleh Nabi Muhammad SAW sebagai calon ahli surge, dan bukan karena mereka masing-masing mewakili kelompok atau suku tertentu. ${ }^{24}$

Setelah “Umar wafat dan dimakamkan, mulailah "tim formatur" -tanpa Thalhah karena tidak berada di Madinah- bentukan 'Umar tersebut mengadakan musyarawah. Sejak semula, jalannya musyawarah benar-benar alot dan ketat. Masing-masing ingin menduduki jabatan khalifah. Abdurrahman bin Awf menawarkan agar ada di antara anggota tim formatur mau mengundurkan diri, namun tidak ada seorangpun yang mau mengundurkan diri. Akhirnya, Abdurrahman bin Awf sendiri yang memulai mengundurkan diri. Setelah itu, dia "melobi" anggota tim formatur lainya, dia menanyakan kepada 'Utsman tentang siapa yang pantas menjadi khalifah seandainya dia tidak terpilih, 'Utsman menjawab: 'Ali. Lalu pertanyaan yang sama diajukan kepada Zubeir dan Sa'ad secara terpisah, keduanya menjawab: 'Usman. Ketika 'Ali bin Abi Thalib disodorkan pertanyaan yang sama, jawaban yang diberikannya juga sama, yaitu: 'Ustman”. ${ }^{25}$

Dari jawaban-jawaban tersebut dapat ditarik kesimpulan bahwa dua kandidat kuatnya adalah 'Utsman dan 'Ali. Polarisasi dua kandidat tersebut tidak hanya di dalam tim formatur, tetapi juga di Masyarakat Madinah. Selanjutnya Abdurrahman bin Awf memanggil 'Ali bin Abi Thalib dan menanyakan seandainya ia terpilih sebagai khalifah sanggupkah dia melaksanakan tugas berdasarkan al-Qur'an dan Sunnah Rasulullah serta kebijaksanaan Abu Bakar dan 'Umar sebelumnya, karena kepolosan dan ke-tawadhu'-anya, 'Ali bin Abi Thalib hanya menjawab bahwa "ia berharap dapat menjalankannya sesuai dengan pengetahuan dan kemampuannya”. Selanjutnya Abdurrahman bin Awf memanggil 'Utsman bin Affan dan menyodorkan pertanyaan yang sama, 'Utsman pun menjawab, "Ya sanggup”. Akhirnya “Utsman pun dibai' at menjadi khalifah ketiga dalam usia 70 tahun. Sementara di pihak lain, 'Ali bin Abi Thalib sangat kecewa dan merasa dirugikan dengan system pemilihan yang

22 Muhammad Iqbal, Fiqh Siyasah: Kontekstualisasi Doktrin Politik Islam, 73.

23 Beni Ahmad Saebani, Figh Siyasah: Terminology dan Lintasan Sejarah Politik Islam Sejak Muhammad SAW, Hingga al-Khulafa' ar Rasyidun, 217.

${ }^{24}$ Munawir Sjadzali, Islam dan Tata Negara: Ajaran, Sejarah, dan Pemikiran, 25.

25 Muhammad Iqbal, Fiqh Siyasah: Kontekstualisasi Doktrin Politik Islam, 74-75. 
dimotori oleh abdurrahman bin Awf, meskipun pada akhirnya 'Ali bin Abi Thalib juga membai'at 'Utsman bin Affan. ${ }^{26}$

Dari system pemilihan yang digariskan tersebut, nampaknya 'Umar merasakan kekuatan politik Islam sudah semakin kuat. 'Umar tidak khawatir akan perpecahan dalam tubuh ummat islam, karena dia telah meletakan sendi-sendi demokrasi dan memperkukuh daulah Islamiyah. Oleh sebab itu dia memberikan kesempatan kepada sahabat sepeninggalnya untuk melaksanakan system musyawarah yang digariskannya dalam memilih khalifah penggantinya. ${ }^{27}$

Dua belas tahun kemudian setelah peristiwa 'Utsman bin Affan diangkat sebagai Khalifah, Ali bin Abi Thalib diangkat menjadi Khalifah keempat melalui pemilihan yang penyelenggaraanya jauh dari kata sempurna. Setelah para pemberontak membunuh 'Utsman bin Affan, mereka mendesak Ali bin Abi Thalib agar bersedia diangkat menjadi khalifah. ${ }^{28}$ Setelah para pemberontak membunuh 'Utsman, para pemberontak mencari beberapa sahabat senior seperti Thalhah, Zubeir, dan Sa'ad bin Abi Waqqash untuk dibai'at menjadi khalifah, namun di antara mereka tidak ada yang bersedia menjadi khalifah. Pada awalnya 'Ali bin Abi Thalib pun tidak bersedia, karena pengangkatanya tidak didukung oleh penduduk Madinah dan veteran perang Badr. Menurut 'Ali, orang yang didukung oleh komunitas inilah yang berhak menjadi khalifah. Akhirnnya Malik al-Sytar al-Nakha’I melakukan bai'at dan diikuti keesokan harinya oleh sahabat besar seperti Thalhah bin Ubaidillah dan Zubeir. Menurut sebuah riwayat, Thalhah dan Zubeir bin Awam membai'at 'Ali bin Abi Thalib di bawah ancaman pedang oleh Malik al-Asytar. ${ }^{29}$

Setelah wafatnya 'Ali bin Abi Thalib karena dibunuh oleh kelompok Khawarij, pengikutpengikutnya mengangkat Hasan bin Ali bin Abi Thalib menjadi khalifah di Kuffah. Sementara di Syam, kedudukan Mu'awiyah pun semakin kokoh didukung oleh penduduknya. Hasan bin Ali bukanlah lawan yang berarti bagi Mu'awiyah. Hasan yang kekuatan politiknya lemah dipaksa mengundurkan diri dari jabatannya dan membuat perjanjian damai dengan Mu'awiyah. Peristiwa ini menandakan rekonsiliasi ummat Islam ('Aam al-jama'ah), setelah ummat islam bertikai beberapa tahun lamanya. Hasan bin Ali pun melakukan bai'at terhadap Mu'awiyah pada tahun $661 \mathrm{M} / 41 \mathrm{H}$, dan diikuti oleh Sebagian besar ummat islam. ${ }^{30}$

Dengan wafatnya 'Ali bin Abi Thalib, maka berakhirlah satu era yaitu era khulafa' al-rasyidin, maka berakhirlah tradisi pengisian jabatan khalifah / kepala negara melalui musyawarah. Mu'awiyah bin Abi Sufyan mendapatkan kedudukan sebagai khalifah tidak melalui musyawarah lagi atau persetujuan dari tokoh-tokoh masyarakat, tetapi melalui ketajaman pedang dan tipu muslihat politik. Kemudian menjelang akhir hayatnya, Mu'awiyah bin Abi Sufyan menunjuk putranya, yaitu Yazid bin Mu'awiyah sebagai "putra mahkota", calon penggantinya kelak. Dari sinilah titik awal lahirnya system monarki atau kerajaan, yaitu pengisian jabatan khalifah / kepala negara yang ditentukan atas dasar keturunan (garis hubungan kekeluargaan), dari situlah mulai dibangun dinasti Umawiyah / Umayah. ${ }^{31}$

Mu'awiyah bin Abi Sufyan, dan para pemimpin dinasti Umayah umumnya, melakukan berbagai penaklukan. Setidaknya, ekspansi dinasti ini meliputi tiga front, yaitu: front pertempuran menghadapi

\footnotetext{
${ }^{26}$ Muhammad Iqbal, Fiqh Siyasah: Kontekstualisasi Doktrin Politik Islam, 75.

27 Muhammad Iqbal, Fiqh Siyasah: Kontekstualisasi Doktrin Politik Islam, 75.

${ }_{28}$ Munawir Sjadzali, Islam dan Tata Negara: Ajaran, Sejarah, dan Pemikiran, 25.

${ }^{29}$ Muhammad Iqbal, Fiqh Siyasah: Kontekstualisasi Doktrin Politik Islam, 85.

30 Muhammad Iqbal, Fiqh Siyasah: Kontekstualisasi Doktrin Politik Islam, 90.

31 Munawir Sjadzali, Islam dan Tata Negara: Ajaran, Sejarah, dan Pemikiran, 34.
} 
bangsa Romawi, di Asia kecil, Konstantinopel, dan pulau-pulau di laut tengah; front Afrika Utara dari selat Gibraltar hingga Spanyol; dan front timur hingga Sindus, India. Hingga akhir kekuasaan Bani Umayyah pada 133 H/ 750 M, kekuasaan Islam sudah sampai lautan Atlantik di Barat, dan lembah Indus di Timur. ${ }^{32}$

Karena dilanda berbagai krisis politik yang melemahkan kerajaan dinasti Umayyah, salah satunya adalah gerakan opisisi yang terus menggerus dan memperlemah kekuatan dinasti Umayyah. Di antara yang paling bahaya adalah Gerakan Khawarij di Oman, Syi'ah di Kuffah, dan Gerakan Abdullah bin Zubeir yang mendapatkan dukungan dar penduduk Hijaz, Yaman, Irak, dan Iran. Akhirnya pada tahun 133 H / 750 M, revolusi Bani Abbas berhasil menghancurkan kekhilafahan Umayyah. Peta politik umat islam pun berganti dan “dikuasai kembali” oleh keluarga Bani Hasyim. ${ }^{33}$

Dinasti Bani Abbas ditegakkan secara revolusi di atas sisa-sisa kekuatan Bani Umayyah. Setelah berhasil menggulingkan khalifah Marwan II, khalifah terakhir bani Umayyah pada tahun $133 \mathrm{H} / 750$ M, Abu al-'Abbas al-Saffah memproklamirkan berdirinya kerajaan Bani Abbas. Meskipun al-Saffah merupakan pendiri dari dinasti ini, orang yang berjasa mengembangkan dinasti 'Abbassiyah adalah Abu Ja'far al-Manshur (137-159 H / 754-775 M). Kebijakan terpenting yang dilakukan oleh khalifah al-Manshur adalah memindahkan ibu kota kerajaan ke Baghdad pada tahun 145 H / 762 M. ${ }^{34}$

Pada mulanya pusat pemerintahan dinasti Abbasiyah adalah di Kuffah. Namun kota ini kurang aman, karena Kuffah merupakan basis pendukung Syi'ah yang sangat pro terhadap 'Ali bin Abi Thalib. Oleh sebab itu, al-Saffah memindahkan ibu kota ke Hasyimiyah, dekat Kuffah. Namun demikian, di kota Hasyimiyah juga belum aman dari oposisi Syiah, karena masih dekat dengan Kuffah. Akhirnya pada masa kekhalifahan al-Manshur, ibu kota dipindahkan ke Baghdad. Pilhan kota Baghdad sangatlah tepat karena posisinya yang terletak di delta sungai Tigris. ${ }^{35}$

Berbeda dengan pemerintahan Bani Umayyah sebelumnya yang mengambil corak secular (memisahkan antara agama dan politik), pemerintahan Bani 'Abbas dalam pemerintahannya menyatukan antara kekuasaan agama dan politik. Perhatian mereka terhadap agama tentu tidak lepas dari pertimbangan politis, yaitu memperkuat posisi dan melegitimasi kekuasaan mereka terhadap rakyat. Pemanfaatan Bahasa agama ini terlihat pertama kali dari pernyataan al-Manshur bahwa dirinya adalah wakil Allah di bumi (dzillu Allah fi al-ardhi). Pernyataan al-Manshur ini telah menggeser pengertian khalifah sebelumnya dalam Islam. Abu Bakar sebagai khalifah pertama dalam politik islam, tidak menyatakan diri sebagai khalifatu Allah (pengganti Allah), tetapi menyatakan diri sebagai khalifatu al-rasulullah (pengganti rasul sebagai pemimpin).

Pernyataan al-Manshur tersebut di atas bawa khalifah memerintah berdasarkan mandat Tuhan, bukwn mandate dari rakyat. Oleh karena itu, kekuasaan para khalifah bersifat suci dan mutlak, serta harus ditaati oleh ummat islam, karena khalifah berkuasa dalam masalah politik kenegaraan dan agama sekaligus.

Dengan kata lain, raja-raja yang berkuasa boleh menggunakan istilah atau gelar khalifah. Hal ini karena menurut Ibn Taimiyah yang penting ada seorang pemimpin negara ketimbang tidak ada, meskipun bentuknya kerajaan asalkan para pemimpinnya menjaga agama dan keadilan. Jika ulama

\footnotetext{
${ }_{32}$ Muhammad Iqbal, Fiqh Siyasah: Kontekstualisasi Doktrin Politik Islam, 91.

${ }_{33}$ Muhammad Iqbal, Fiqh Siyasah: Kontekstualisasi Doktrin Politik Islam, 97.

34 Muhammad Iqbal, Fiqh Siyasah: Kontekstualisasi Doktrin Politik Islam, 97.

35 Muhammad Iqbal, Fiqh Siyasah: Kontekstualisasi Doktrin Politik Islam, 97-98.
} 
klasik dan pertengahan lebih banyak memberikan sumbangan pemikiran kepada usaha perbaikan dan saran-saran terhadap pemerintahan yang sudah ada, menjelang akhir abad XIX atau yang dikenal masa kontemporer pemikiran politik Islam mulai mengalami pergeseran yang signifikan dan berkembanglah pluralitas pemikiran tentang sistem khilafah. ${ }^{36}$

\section{Diskursus Khilafah Era Kontemporer}

Dalam konteks pemikiran politik Islam kontemporer, respon umat Islam dalam menghadapi hal yang baru, kemajuan Barat di satu sisi dan kemunduran umat Islam di sisi yang lain, memunculkan tiga ideologi politik Islam kontemporer, ${ }^{37}$ yaitu: ideologi reformis (menerima sistem Barat dengan kritis dan mencari titik temunya dengan ajaran Islam), ideologi sekularis (menerima sistem Barat), dan ideologi tradisionalis (menolak sistem Barat).

Sebelum membahas tentang berbagai ideologi politik Islam kontemporer tersebut, terlebih dahulu perlu disinggung tentang dua tokoh penting dalam pembaharuan Islam, yaitu Jamal al-Din al-Afghani (1838-1897 M) dan Muhammad 'Abduh (1849-1905 M). Jamal al-Din al-Afghani dilahirkan pada tahun $1838 \mathrm{M}$, masa kecilnya dihabiskan di Afganistan. Dia belajar segala cabang ilmu keislaman, filsafat, dan ilmu eksakta sampai umur 18 tahun. Dia juga pernah bekerja di Dinas Pemerintahan Afganistan. Selama hidupnya, al-Afghani pernah tinggal di beberapa tempat, yaitu: India, Kairo, Istanbul, Iran, London dan Paris. Dan dia meninggal pada tahun $1897 \mathrm{M}^{38}$

Muhammad 'Abduh dilahirkan di Mesir hilir pada tahun 1849 M. Dia awalnya belajar ilmu agama, setelah dia masuk al-Azhar di Kairo perhatiannya terpusat pada pelajaran tasawuf dan kehidupan Sufi. Pada tahun 1872 - di usianya yang ke-23 tahun- dia bertemu dengan al-Afghani. 'Abduh belajar dari al-Afghani untuk melihat agama dalam perspektif berbeda. Al-Afghani juga yang memperkenalkan 'Abduh dengan karya-karya penulis Barat serta mendorong 'Abduh untuk belajar ilmu jurnalistik. Selanjutnya al-Afghani juga yang membuka kesadaran 'Abduh tentang masalah-masalah sosial dan politik yang dihadapi masyarakat Mesir khususnya dan masyarakat Islam pada umumnya. ${ }^{39}$

Dua tokoh inilah yang nantinya -sedikit banyak- menjadi inspirasi sekaligus guru dari para pemikir politik Islam kontemporer, baik yang menganut ideologi sekularis, tradisionalis, maupun yang menganut ideologi reformis. Jadi dengan kata lain, dua tokoh ini merupakan "bapak kandung" sekaligus "titik persimpangan" dari berbagai ideologi politik Islam kontemporer yang ada.

Para pendukung dari ideologi reformis antara lain adalah Muhammad Husayn Haikal (18881956 M) dan Fazlur Rahman (1919-1988 M). Dalam pemikiran politik Haikal, di dalam Qur'an dan Sunnah tidak ditemukan aturan-aturan langsung dan rinci mengenai persoalan kenegaraan, Qur'an

\footnotetext{
${ }^{36}$ Irfan Ardiansyah, "Pergeseran Dari Sistem Khilafah Ke Nation State Dunia Islam”, UIR Law Review Volume 01, Nomor 02, Oktober 2017.

37 Menurut kelompok tradisionalis agama Islam adalah agama yang lengkap memuat tentang sistem sosial, ekonomi, hukum, dan politik sehingga umat Islam tidak perlu meniru Barat. Sedangkan menurut kelompok sekularis dalam kenyataan sejarah (era Nabi SAW dan shahabat) Islam adalah semata-mata agama, sehingga Islam harus dipisahkan, khususnya, dari politik. Sehingga tidak ada salahnya umat Islam meniru Barat yang dalam kenyataanya lebih maju. Sedangkan menurut kelompok reformis, Islam bukan semata-mata agama yang hanya mengatur kehidupan manusia dengan Tuhan, namun juga bukan agama yang mengatur secara lengkap dan rinci mengenai sistem politik (tatanegara). Karena tatanegara bukan merupakan ibadah murni (mahdah) maka umat Islam dapat secara selektif meniru Barat yang dalam kenyataanya lebih maju, namun itu semua dilakukan dalam rangka kemajuan Islam. Lihat Munawir Sjadzali, Islam dan Tatanegara, 115-116. Lihat pula Musdah Mulia, Negara Islam, 21-22.

38 Munawir Sadzali, Islam dan Tata Negara, 117-120.

39 Munawir Sadzali, Islam dan Tata Negara, 120.
} 
dan Sunnah hanya memberikan seperangkat nilai yang dapat digunakan sebagai pijakan dasar bagi pengaturan kehidupan bersama, termasuk dapat juga dijadikan landasan dasar bagi pengelolaan negara. ${ }^{40}$

Dalam konsepsi Fazlur Rahman masyarakat Islam adalah masyarakat yang moderat dan para penguasanya (ulil al-amri) adalah elitnya. Masyarakat Islam juga adalah masyarakat yang egaliter, terbuka (inklusif), saling berbuat baik dan bekerjasama, dan tidak melakukan diskriminasi berdasarkan gender atau kulit. Dalam konsepsi Rahman Shura (musyawarah) -yang menjadi dasar dari demokrasi- adalah proses timbal balik melalui diskusi. Rahman menerima konsep demokrasi, namun demokrasi yang dia maksud adalah demokrasi yang berorientasi pada etika dan nilai spiritual Islam, bukan demokrasi yang bersifat material seperti di Barat. ${ }^{41}$ Para pendukung dari ideologi sekularis antara lain adalah: Ahmad Lutfi Sayyid (1872-1963 M), Taha Husain (1889-1973 M) 'Ali ‘Abd al-Raziq (1888-1966 M), ${ }^{42}$ dan Mohammed Arkoun (1928-2010 M).

Pemikiran Lutfi Sayyid berkaitan dengan beberapa hal, yaitu: lebih menekankan identitas nasional (Mesir) daripada Islam; pemisahan agama dan negara; serta perlunya umat Islam meniru secara selektif sistem politik dan sosial Barat. Sedangkan dalam pemikiran Taha Husain bahwa cara untuk memajukan Islam adalah dengan perubahan-perubahan total dengan semangat liberalisme dan sekularisme dengan meniru Barat, Husain juga berpendapat bahwa dalam sejarahnya Islam dan negara selalu terpisah, sedangkan pengaturan konstitusi negara didasarkan pada landasan-landasan praktis. ${ }^{43}$

Sedangkan Raziq berpendapat bahwa mendirikan khilafah bukanlah merupakan kewajiban umat Islam, pemerintahan tidak harus berbentuk khilafah, dan Nabi SAW adalah semata-mata adalah utusan Allah SWT yang bertugas mendakwahkan agama murni tanpa maksud mendirikan negara / kerajaan. ${ }^{44}$ Kalaupun Nabi SAW memiliki kekuasaan, kekuasaanya bersifat umum mencakup persoalan dunia dan akhirat. Kekuasaan ini diperlukan sebagai sarana mendukung tugas beliau. Gagasan Raziq ini tertuang dalam karyanya al-Islam wa al-usul al-hukm. ${ }^{45}$

Senada dengan Raziq, dalam pemikiran Arkoun bahwa dimensi sekularisme dalam pemikiran Islam dapat ditemukan di dalam Qur'an dan pengalaman Madinah, dinasti Umayyah dan abasiyah pun merupakan negara selular. Teorisasi idelogi yang digunakan oleh para fuqaha adalah dalam rangka menyembunyikan realitas sejarah dan politik. Dalam kenyataan sejarah militerlah yang memainkan peran yang sangat penting dalam kekhalifahan dan pemerintahan Islam. ${ }^{46}$

Pada posisi yang berseberangan dengan ideologi sekuler tersebut di atas ditempati oleh ideologi tradisionalis. Para pendukung ideologi ini antara lain adalah: Muhammad Rashid Rida (1865-1935 M), al-Ikhwan al-Muslimun dan para tokohnya; Hasan al-Bana (1906-1949 M) dan Sayyid Qutb (1906-1966 M). Pendukung ideologi tradisionalis lainya adalah Abu al-A'la al-Maududi (1903-1979 M) beserta Jama at-i al-Islami. Para pendukung ideologi tradisionalis ini juga biasa disebut dengan Salafi. ${ }^{47}$ Dalam

\footnotetext{
40 Musdah Mulia, Negara Islam, 22.

${ }^{41}$ Sukron Kamil, "Peta Pemikiran Politik Islam Modern dan Kontemporer" Jurnal Universitas Paramadina 3, no. 1, September (2003): 72

42 Munawir Sjadzali, Islam dan Tatanegara, 138.

43 Munawir Sjadzali, Islam dan Tatanegara, 138-139.

${ }^{44}$ Munawir Sjadzali, Islam dan Tatanegara, 140-142.

45 Musdah Mulia, Negara Islam, 220.

46 Nazih N Ayubi, Political Islam; Religion and Politics in The Arab World (London: Ruotledge, 1991), 54.

47 Salafi adalah aliran keagamaan yang berkeyakinan bahwa untuk memulihkan kejayaan Islam umat Islam harus kembali
} 
pemikiran kelompok Salafi ini tuntutan untuk penerapan syariah adalah penerapan hukum (fikih) yang telah diformulasikan (dibentuk) oleh para ahli fikih pada masa awal (Salaf al-Salih). ${ }^{48}$ Di samping para penganut ideologi Salafi di atas- yang beraliran Sunni, para penganut Shi'ah juga memiliki pandangan yang sama bahwa negara dalam perspektif Shi'ah bersifat teokratis, kekuasaan mutlak berada pada Allah SWT dan konstitusi negara didasarkan pada wahyu Allah SWT (Shari'ah). ${ }^{49}$

Dalam pandangan Rida (1865-1935 M), kekhilafahan Turki Usmani harus terus dipertahankan. Kekhalifahan Turki ini perlu terus didukung dan diperkuat wibawa serta kemampuanya dalam menghadapi kekuatan asing. Sebagai reaksi atas tindakan Mustafa Kamal At-Tatuk yang membekukan kekuasaan Sultan pada 1922 M, Rida mengeluarkan gagasan untuk menghidupkan kekhalifahan baru..$^{50}$ Gagasan Rida tentang kekhilafahan tertuang dalam karyanya al-Khilafah yang ditulis antara tahun 1922-1923 M. ${ }^{51}$

Untuk merealisasikan gagasanya untuk menghidupkan kekhalifahan, Rida membuat programprogram yaitu: ${ }^{52}$ Pertama, menentukan tempat kedudukan khalifah baru. Dia mengusulkan agar tempatnya secara geografis terletak di tengah-tengah dunia Islam, misalnya di kota Masul-Irak. Kedua, cara mempersiapkan khalifah. Seorang khalifah harus memiliki keilmuan yang mendalam dan wawasan yang luas, oleh sebab itu perlu diselenggarakan lembaga pendidikan calon-calon khalifah. Calon khalifah dipilih dari dan oleh para lulusan pendidikan tersebut, setelah terpilih khalifah dikukuhkan oleh Ahlu al-halli wa al-'aqdi. Ketiga, Muktamar akbar. Untuk membentuk kekhalifahan baru dia mengusulkan diselenggarakan muktamar akbar. Muktamar ${ }^{53}$ ini diselenggarakan pada tahun 1926 di Mesir, namun muktamar ini tidak menghasilkan keputusan apapun.

Sedangkan dalam pemikiran Hasan al-Bana, Islam adalah agama yang sempurna dan lengkap dengan segala sistem yang dibutuhkan oleh kehidupan umat Islam baik sistem politik, ekonomi, dan sosial. Umat Islam tidak perlu meniru Barat untuk menggapai kemajuan Islam kembali. Sebagaimana gurunya (Rida), al-Bana menekankan perlunya didirikan pemerintahan (negara) Islam dan diberlakukannya hukum Islam. ${ }^{54}$ Pemikiran al-Bana inilah yang kemudian menjadi landasan ideologis bagi organisasi al-Ikhwan al-Muslimun yang didirikannya pada $1928 \mathrm{M}$.

Dalam ideologi al-Ikhwan al-Muslimun, pemerintahan (negara) bukanlah sesuatu yang terpisah dari agama, sebaliknya pemerintahan (negara) adalah salah satu pilar dari agama. Islam adalah hukum sekaligus penerapannya. Oleh karena itu diamnya para pembaharu Islam terhadap pemberlakuan

\footnotetext{
kepada ajaran Islam yang masih murni seperti yang dipraktekan oleh generasi Islam pertama (salaf). Gagasan pemikiran Salafi ini awalnya dipelopori oleh Ibnu Taymiyah (1263-1329 M) dan Muhammad Ibn 'Abd al-Wahhab (w. 1791 M). Pada abad ke-19 M pemikiran Salafi ini dipelopori oleh Jamal al-Din al-Afghani (1838-1897 M), dan diikuti oleh murid al-Afghani; Muhammad 'Abduh (1849-1905 M), dan murid 'Abduh; Muhammad Rashid Rida (1865-1935 M). Ada tiga komponen utama dalam gagasan Salafi al-Afghani (Salafi abad 19 M), yaitu; (1) Untuk menggapai kejayaan Islam, umat Islam harus kembali pada ajaran Islam yang murni, dan meneladani pola hidup sahabat terutama al-Khulafa al-Rashidun, (2) Perlawanan terhadap kolonialisme dan dominasi politik, ekonomi maupun kebudayaan Barat, (3) Pengakuan terhadap keunggulan ilmu dan teknologi Barat sehingga umat Islam perlu belajar dari Barat. Lihat Munawir Sjadzali, Islam dan Tatanegara, 124-125.

${ }^{48}$ Nazih N Ayubi, Political Islam, 2.

49 Marzuki Wahid dan Rumadi, Fiqh Madzhab Negara: Kritik Atas Politik Hukum Islam di Indonesia (Yogyakarta: LKiS, 2001$), 24$.

50 Munawir Sjadzali, Islam dan Tatanegara, 127.

51 Antony Black, Pemikiran Politik Islam; dari Masa Nabi Hingga Masa Kini. Terj. Abdullah Ali dkk. (Jakarta: Serambi Ilmu Semesta, 2006), 565.

52 Munawir Sjadzali, Islam dan Tatanegara, 135-137.

53 Dalam muktamar ini para peserta terbagi menjadi tiga kelompok, yaitu; Pertama, yang menginginkan khalifah yang baru adalah Sultan Abdul Majid (yang telah diturunkan oleh Mustafa Kamal). Kedua, khalifah yang baru adalah penguasa Hijaz Syarif Husein. Ketiga, khalifah yang baru adalah Raja Fuad dari Mesir. Lihat Munawir Sjadzali, Islam dan Tatanegara, 137.

${ }^{54}$ Munawir Sjadzali, Islam dan Tatanegara, 147.
} 
hukum Islam adalah dosa besar yang tidak terampuni ${ }^{55}$ kecuali dengan mengambil alih pemerintahan dari tangan orang yang tidak mau menegakkanya. Islam tidak diturunkan dalam keadaan tanpa undang-undang, sebaliknya secara lengkap Islam telah menjelaskan asas-asas perundang-undangan dan perincian hukum baik perdata, pidana, hukum perdagangan, maupun hukum kenegaraan. ${ }^{56}$

Al-Ikhwan al-Muslimun secara lebih khusus mendefinisikan ideologinya dalam tiga hal sebagai berikut ${ }^{57}$ : Pertama, Islam adalah agama yang menyeluruh dan lengkap dengan sendirinya (mutakamil bi zatihi), Islam adalah muara dari seluruh ruang lingkup kehidupan. Kedua, Islam terpancarkan dan didasarkan pada dua sumber utama; Qur'an dan Hadis. Qur'an dan Hadis ini mencakup seluruh aspek kehidupan manusia termasuk persoalan politik. Ketiga, Islam adalah agama yang dapat diterapkan pada setiap zaman dan tempat. Dalam pemikiran al-Ikhwan al-Muslimun negara Islam yang diidealkan adalah negara yang didasarkan pada tiga keyakinan tersebut. Umat Islam berkewajiban berjuang untuk mendirikan negara Islam, sehingga jika tidak maka seluruh umat Islam berdosa dihadapan Allah.

Dalam pemikiran Sayyid Qutb (1906-1966 M) Qur'an sesungguhnya telah memuat segala sesuatu yang dibutuhkan oleh manusia. Dia menolak pandangan bahwa Islam harus belajar dari Barat tentang bagaimana membangun masyarakat dan politik, dia juga menolak pandangan tentang persamaan antara nilai-nilai Islam dan Barat. ${ }^{58}$ Dalam konteks ini pemikiran Qutb sama dengan pandangan para pemikir tradisionalis lainya.

Dalam konsep al-hakimiyyah-nya, Qutb menyatakan bahwa ketauhidan berarti adalah revolusi melawan segala bentuk pemerintahan manusia beserta segala pengaturannya, hal ini bertujuan dalam rangka menegakkan kekuasaan Tuhan di bumi. ${ }^{59}$ Dengan kata lain, manusia harus mampu membebaskan ketertundukanya kepada sesama manusia dan hanya tunduk pada pemerintahan Tuhan. $^{60}$

Ada tiga hal pokok yang menjadi dasar pemikiran politik Qutb, ${ }^{61}$ yaitu: ${ }^{62}$ Pertama, negara atau pemerintahan Islam berbentuk supra nasional yang meliputi seluruh wilayah Islam dengan sentralisasi kekuasaan pada pemerintahan pusat yang dikelola atas prinsip pemerataan dan persamaan penuh antara semua umat tanpa membedakan suku, ras, bahkan agama. Kedua, persamaan hak antara para pemeluk berbagai agama. Negara Islam menjamin sepenuhnya hak-hak orang-orang zimmi dan kaum musyrik yang terikat dalam perjanjian damai dengan ummat Muslim. Ketiga, politik pemerintahan Islam didasarkan pada tiga asas yaitu: keadilan penguasa, ketaatan rakyat, dan permusyawaratan antara penguasa dan rakyat.

Dalam pemikiran Qutb pemerintahan Islam tidak harus menganut sistem tertentu, pemerintahan Islam bisa menganut sistem apapun karena yang terpenting adalah melaksanakan syariat Islam. Jika

\footnotetext{
55 Untuk mendukung pendapat ini al-Ikhwan al-Muslimun mengemukakan QS. al-Maidah: 44, 45, dan 47, bahwa; barang siapa yang tidak berhukum dengan apa yang diturunkan Allah maka mereka adalah golongan orang-orang yang kafir / yang dzalim / yang fasik. Hasan al-Bana, Risalah Pergerakan al-Ikhwan al-Muslimun 1. Terj. Anis Matta dkk. (Solo: Era Intermedia, 2006$), 277$.

56 Hasan al-Bana, Risalah Pergerakan al-Ikhwan al-Muslimun, 272, 273,

57 Saeful Mujani, Muslim Demokrat; Islam, Budaya Demokrasi, dan Partisipasi Politik di Indonesia Pasca Orde Baru (Jakarta: PT Gramedia Pustaka Utama, 2007), 58.

58 Antony Black, Pemikiran Politik Islam, 578.

59 Nazih N. Ayubi, Political Islam, 140.

60 Antony Black, Pemikiran Politik Islam, 580.

${ }^{61}$ Kendati pada awalnya Qutb diilhami oleh gagasan al-Maududi, Qutb memiliki gagasan tersendiri tentang Islam dan politik. Antony Black, Pemikiran Politik Islam, 577.

62 Munawir Sjadzali, Islam dan Tata Negara, 149-150.
} 
pemerintahan yang berlabel Islam namun tidak melaksanakan syariat Islam, maka pemerintahan tersebut tidak dapat dikatakan sebagai pemerintahan Islam. ${ }^{63}$

Pemikir politik Islam kontemporer lain yang menganut ideologi tradisionalis adalah Abu alA'la al-Maududi (1903-1979 M) seorang pemikir kelahiran Aurangabad-India tengah. Pada 1941 M al-Maududi mendirikan Jama 'at-i Islami, ${ }^{64}$ kemudian dia berpindah ke negara baru Pakistan yang didirikan pada 1947 M. ${ }^{65}$ Gagasan politik al-Maududi didasarkan pada tiga keyakinan: Pertama, Islam adalah agama yang paripurna, lengkap memuat seluruh aturan kehidupan termasuk aturan politik. Kedua, kedaulatan tertinggi ada pada Allah, bukan ada pada manusia (rakyat). Ketiga, sistem politik Islam adalah sesuatu yang universal dan tidak mengenal batas-batas dan ikatan-ikatan geografi, bahasa, dan kebangsaan. ${ }^{66}$ Karena Allah adalah pemegang kedaulatan tertinggi (al-hakimiyyah), maka hak membuat undang-undang sepenuhnya ada pada Allah, sehingga umat Islam tidak boleh mengubah ketentuan-ketentuan hukum Allah, dan tugas negara Islam adalah melaksanakan hukum Allah. ${ }^{67}$ Atas dasar prinsip tersebut al-Maududi merumuskan konsepsi politiknya tentang sistem pemerintahan Islam.

Ada enam hal dalam konsepsi pemikiran politik al-Maududi, yaitu: ${ }^{68}$ Pertama, sistem kenegaraan Islam tidak menganut sistem demokrasi, namun menganut sistem teokrasi ${ }^{69}$ atau dikenal juga dengan konsep teodemokrasi. Kedua, hak membentuk, mengangkat dan memberhentikan pemerintah (badan eksekutif) ada pada umat Islam. Ketiga, kekuasaan negara terdiri dari tiga lembaga, yaitu: eksekutif (lembaga ini dikepalai oleh kepala negara), legislatif (majlis shura), dan judikatif (badan ini bersifat independen).

Keempat, syarat-syarat kepala negara: Islam, laki-laki, dewasa, sehat fisik dan mental, warga negara yang terbaik, shaleh dan berkomitmen kuat pada Islam. Kelima, keanggotaan legislatif (majlis shura) terdiri dari warga negara yang Islam, dewasa dan laki-laki, soleh, serta terlatih dalam menafsirkan dan menerapkan syariah tanpa bertentangan dengan Qur'an dan Hadis. Keenam, dalam negara Islam terdapat dua kategori kewarganegaraan: Islam dan non Islam (zimmi). Warga negara non Muslim memiliki hak yang sama seperti warga Muslim, namun tidak memiliki hak untuk menduduki jabatan-jabatan kunci, serta tidak berkewajiban dalam bela negara.

Pada 1952 M di al-Quds muncul gerakan politik Hizb al-Tahrir yang didirikan oleh Taqiyu alDin al-Nabhani (1909-1977 M). Meskipun gerakan ini memiliki pola gerakan yang berbeda dengan kelompok Salafi - misalnya al-Ikhwan al-Muslimun, namun dalam konteks pemikiran, gerakan Hizb al-Tahrir ini memiliki akar geneologis pemikiran yang sama. Taqiyu al-Din pernah berguru dengan beberapa ulama yang merupakan murid langsung dari Muhammad Rashid Rida, dan pemikiran

\footnotetext{
63 Munawir Sjadzali, Islam dan Tata Negara, 151.

${ }^{64}$ Pada awalnya gerakan ini lebih merupakan gerakan ideologis daripada gerakan politik. Gerakan ini didirikan oleh al-Maududi bersama 70 pengikutnya. Keanggotaan organisasi ini bersifat ekslusif -hanya terbatas pada orang-orang Islam yang saleh. Orientasi program dari gerakan ini adalah pembentukan pribadi dan doktrinasi para anggotanya agar siap memimpin negara Islam pasca lepasnya India dari jajahan Inggris. Lihat Munawir Sjadzali, Islam dan Tata Negara, 163.

${ }^{65}$ Nazih N. Ayubi, Political Islam, 128

66 Munawir Sjadzali, Islam dan Tata Negara, 157.

67 Saeful Mujani, Muslim Demokrat, 61.

68 Munawir Sjadzali, Islam dan Tata Negara, 166-169.

69 Sistem teokrasi dalam konsepsi al-Maududi berbeda dengan konsepsi teokrasi yang dikenal di Eropa yang menempatkan kelas sosial pendeta sebagai pemegang otoritas kekuasaan negara atas nama Tuhan. Sedangkan konsepsi teokrasi yang dimaksud adalah kedaulatan Tuhan (the Sovereignty of God) ada di tangan umat Islam dengan berpedoman pada Qur'an dan Sunnah. Munawir Sjadzali, Islam dan Tata Negara, 166-167.
} 
Taqiyu al-Din akan bertemu dengan pemikiran Salafi pada Ibnu Taymiyah dan Ahmad Ibn Hanbal. Dan dalam batas tertentu, Hizb al-Tahrir ini adalah merupakan pengembangan dari gagasan pemikiran Rida, 'Abduh, dan Afghani. ${ }^{70}$ Di samping Hizb al-Tahrir, gerakan Wahabi (para pengikut Muhammad Ibn 'Abdu al-Wahab) di Arab Saudi juga memiliki doktrin penyatuan agama dan negara, ${ }^{71}$ bahkan di dalam praktek kenegaraannya, di Arab Saudi konstitusinya didasarkan pada Qur'an dan Hadis. Oleh sebab itu maka, dua gerakan ini juga dapat dimasukan dalam kategori penganut ideologi politik tradisionalis.

Di samping para pemikir dan penganut ideologi tradisionalis di atas, yang merupakan kelompok Sunni, muncul juga pemikir politik dari kalangan Shi'ah yaitu Ayatullah Ruhullah Khomeini (19021989 M) yang mengusung tentang penyatuan agama dan negara melalui konsepsi wilayah al-faqih (pemerintahan oleh para ulama). ${ }^{72}$ Pemikiran politik Shi' ah kontemporer ini juga dapat dikategorikan sebagai penganut ideologi politik Islam tradisonalis.

Al-Maududi menyebutkan bahwa doktrin tentang khilafah yang disebutkan al-Qur'an ialah bahwa segala sesuatu di atas bumi ini hanyalah karunia dari Allah, dan Allah telah menjadikan manusia dapat menggunakan pemberian-pemberian sesuai petunjuk-Nya. Berdasarkan ini, maka manusia bukanlah penguasa atau pemilik dirinya sendiri, tetapi ia hanyalah khalifah atau wakil Allah yang sebenarnya. Selanjutnya, al-Maududi menyebutkan bahwa Islam menggunakan istilah kekhalifahan bukannya kedaulatan. Karena dalam Islam kedaulatan hanya milik Tuhan saja, siapa pun yang memegang tampuk kekuasaan dan siapa pun yang memerintah sesuai dengan hukum Tuhan pastilah merupakan khalifah dari penguasa tertinggi dan tidak akan berwenang mengerahkan kekuasaan apapun kecuali kekuasaan-kekuasaan yang telah didelegasikan kepadanya. ${ }^{73}$

Sedangkan menurut Ali Abdul Raziq, baik alQur'an, hadis, maupun ijma', yang berbicara tentang bai'at, hukm (pemerintahan), atau perintah untuk menaati uli al-amr, arahnya bukan perintah untuk mendirikan khilafah. Perintah untuk bai'at, atau menaati uli al-amr, sama sekali bukan berbicara tentang teori imamah, dan bukan kewajiban agama. Juga tidak berarti Allah telah menetapkan hukum tertenu bagi masalah-masalah imamah. Sedangkan ijma' merupakan sesuatu yang sulit dicari sandarannya dan keotentikannya. Berdasarkan uraian di atas dapat diketahui bahwa dasar hukum khilafah adalah al-Qur'an, hadis, ijma' sahabat, dan alasan logika. Namun demikian, baik ayat-ayat al-Qur'an, hadis, maupun ijma' di atas masih diperdebatkan oleh para ulama tentang keterkaitannya dengan pembentukan khilafah. ${ }^{74}$

Munculnya pemikiran politik Islam kontemporer, banyak dilatarbelakangi oleh tiga faktor. Pertama, faktor kemunduran dan kerapuhan dunia Islam yang disebabkan faktor-faktor internal, dan yang berakibat munculnya gerakan-gerakan pembaharuan dan pemurnian Islam. Kedua, karena hegemoni Barat terhadap keutuhan kekuasaan politik dan wilayah dunia Islam yang berujung dengan dominasi atau penjajahan oleh negara-negara Barat atas sebagian besar wilayah dunia Islam, hingga

\footnotetext{
$\overline{70}$ Jamhari dan Jajang Jahroni, Gerakan Salafi di Indonesia (Jakarta: PT. Raja Grafindo Persada, 2004), 168, 176-177.

71 Arskal Salim, Challenging the Secular State: The Islamization of Law in Modern Indonesia (Honolulu: University of Hawai'i Press, 2008), 27.

72 Arskal Salim, Challenging the Secular State, 29.

${ }^{73}$ Irfan Ardiansyah, "Pergeseran Dari Sistem Khilafah Ke Nation State Dunia Islam”, UIR Law Review Volume 01, Nomor 02, Oktober 2017.

${ }^{74}$ Irfan Ardiansyah, "Pergeseran Dari Sistem Khilafah Ke Nation State Dunia Islam”, UIR Law Review Volume 01, Nomor 02, Oktober 2017.
} 
runtuhnya kekhilafahan Turki Utsmani. ${ }^{75}$

Ketiga, karena keunggulan Barat dalam bidang ilmu, teknologi, organisasi dan politik. Tiga hal di atas sangat mewarnai orientasi para pemikir politik Islam kontemporer. Umumnya orientasi pemikirannya pada wilayah pembaharuan dan pemurnian Islam dengan berbagai nuansanya. Namun demikian dalam gagasan pemerintahan terdapat visi yang beragam. Ada yang menarik dari gagasan Abduh terhadap sistem pemerintahan Islam. Tidak ada salahnya umat Islam berkiblat kepada Barat dalam pola pemerintahan, jika pola tersebut tidak secara jelas dilarang oleh al-Qur'an maupun Sunnah. Artinya, pemerintahan Islam tidak harus berbentuk khilafah, tapi boleh republik jika dipandang lebih baik. ${ }^{76}$

Gagasan yang hampir sejalan adalah Husain Haikal. Menurut Haikal prinsip-prinsip dasar kehidupan kemasyarakatan yang diberikan oleh alQur'an dan Sunah tidak adayang langsung berkaitan dengan ke-khalifahan. Kehidupan bernegara bagi umat Islam itu baru mulai pada waktu Nabi berhijrah dan menetap di Madinah. Nabi mulai meletakkan ketentuan-ketentuan dasar bagi kehidupan keluarga, pembagian waris, usaha dan jual beli. Ayat-ayat yang diwahyukan dalam periode Makkah terbatas pada ajakan untuk menegaskan Tuhan dan keimanan, serta nilai-nilai kemanusiaan yang tinggi. Bahkan ketentuanketentuan dasar tentang kehidupan bermasyarakat, kehidupan ekonomi dan budi pekerti tersebut belum menyentuh secara rinci dasar-dasar bagi kehidupan bernegara, apalagi langsung menyinggung sistem pemerintahan. ${ }^{77}$

Islam tidak mengenal adanya kekuasaan agama. Islam tidak memberikan kekuasaan kepada seseorang atau kelompok untuk menindak orang lain atas nama agama. Islam juga tidak membenarkan campur tangan penguasa dalam kehidupan dan urusan keagamaan orang lain dan tidak mengakui hak seseorang untuk memaksakan pengertian, pendapat dan penafsirannya tentang agama atas orang lain. Salah satu prinsip dari ajaran Islam adalah mengikis habis kekuasaan keagamaan, sehingga setelah Allah dan Rasul-Nya tidak ada seorangpun yang mempunyai kekuasaan atas akidah dan iman orang lain. ${ }^{78}$

Pandangan Abduh ini kiranya yang mendorong sahabat dan muridnya cenderung ke arah paham nasionalisme dan sekularisme seperti Lutfi Sayyid, Thaha Husaen dan Ali Abd al-Raziq. Bahkan Abdul Raziq mempertanyakan dasar anggapan bahwa mendirikan pemerintahan dengan pola khilafah merupakan keharusan agama. Apabila ditinjau dari segi agama maupun rasio, pola pemerintahan khilafah itu tidak relevan. Raziq membedakan antara misi kenabian dengan pemerintahan. Misi kenabian bukanlah pemerintahan dan agama itu bukan negara dan harus dibedakan mana yang Islam dan mana yang Arab, mana yang agama dan mana yang politik. Raziq tidak sependapat dengan kebanyakan ulama yang menyatakan bahwa mendirikan khilafah merupakan suatu kewajiban, dan tidak ada satupun dasar yang mewajibkan itu, baik al-Qur'an, hadits maupun ijma'. Memang, ijma' merupakan sumber ketiga hukum Islam setelah al-Qur'an dan Sunnah. Abu Bakar sebagai khalifah pertama, sampai sekarang tidak pernah dilakukan dengan ijma'. Bahkan hampir semua khalifah dari

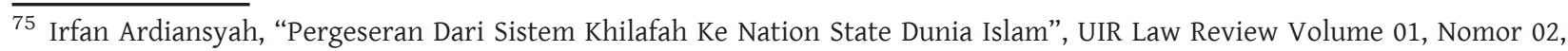
Oktober 2017.

${ }^{76}$ Irfan Ardiansyah, “Pergeseran Dari Sistem Khilafah Ke Nation State Dunia Islam”, UIR Law Review Volume 01, Nomor 02, Oktober 2017.

77 Irfan Ardiansyah, “Pergeseran Dari Sistem Khilafah Ke Nation State Dunia Islam”, UIR Law Review Volume 01, Nomor 02, Oktober 2017.

78 Irfan Ardiansyah, "Pergeseran Dari Sistem Khilafah Ke Nation State Dunia Islam”, UIR Law Review Volume 01, Nomor 02, Oktober 2017. 
zaman ke zaman dinobatkan dan dipertahankan dengan kekuatan fisik dan ketajaman senjata. ${ }^{79}$

Selanjutnya Raziq berpendapat bahwa dalam hidup bermasyarakat tiap kelompok manusia memerlukan penguasa yang mengatur dan melindungi kehidupan mereka, lepas dari agama dan keyakinan mereka, apakah Islam, Nasrani, Yahudi atau mereka yang tidak beragama sekalipun. Penguasa itulah pemerintah. Namun pemerintah itu tidak harus berbentuk khalifah, melainkan dapat beraneka ragam bentuk dan sifatnya, apakah konstitusional atau kekuasaan mutlak, apakah republik atau diktator dan sebagainya..$^{80}$

Tegasnya, tiap bangsa harus mempunyai pemerintahan, tetapi baik bentuk maupun sifatnya tidak harus satu, khalifah, dan boleh beragam. Sementara pemikir politik Islam lain seperti Maududi berpendapat bahwa Islam adalah suatu agama yang paripurna, yang mengatur segala aspek kehidupan, dan mendirikan khilafah Islam merupakan kewajiban yang tidak bisa ditawar. Demikian juga pendapat Rasyid Ridha, Hasan al-Bana maupun Sayyid Qutb. Secara umum, teori-teori pemerintahan yang mereka ajukan terdapat kesamaan, misalnya bahwa pola pemerintahan Islam adalah universal yang tidak mengenal batas-batas dan ikatan-ikatan geografis, bahasa maupun kebangsaan. ${ }^{81}$

\section{Penutup}

Istilah khilafah dalam praktek politik Islam pertama kali muncul di era kepemimpinan Abu Bakar. Kepemimpinan Abu Bakar sebagai pemimpin disebut sebagai khalifatu al-nabi (pengganti kepemimpinan Nabi) setelah dia terpilih melalui pertemuan terbatas di Tsaqifah Bani Sa'idah.

Kata khilafah dapat ditemukan di dalam QS. Q.S. Al-Baqarah: 30, dan QS Shad ayat 26. Jika dilihat di dalam dua ayat al-Qur'an tersebut, istilah khalifah mempunyai dua makna, yaitu: Pertama, Khalifah yang bermakna manusia, yang dalam hal ini adalah Nabi Adam. Kedua, khalifah yang bermakna penguasa, orang yang memiliki kekuasaan politik yang dapat mengatur masyarakat, yang juga bermakna pemimpin,

Konsep khilafah dalam praktek politik islam masa klasik dapat dibagi menjadi dua, yaitu khilafah (1) era khulafa' al-rasyidin, dan (2) era pasca khulafa' al-rasyidin. Era khulafa' al-rasyidin ini memiliki ciri kha di mana para pemimpin (khalifah atau Amirul mu'minin) dipilih dengan tata cara musyawarah, meski tata cara musyawarahnya berbeda-beda. Karakter kepemimpinannya juga memiliki ciri-ciri demokratis, dimana para khalifah menomorsatukan kepentingan ummat islam di atas kepentingan pribadi dan golongan. Sedangkan pada era pasca khulafa' al-rasyidin, proses pengangkatan pemimpin dilakukan dengan tatacara turun-temurun berdasarkan garis keturunan atau hubungan kekeluargaan. Diskursus khilafah pada era klasik memiliki karakter yang khas, yaitu tema-tema yang dibahas adalah seputar tata cara pengangkatan pemimpin, syarat-syarat pemimpin, etika politik dll. Sedangkan diskursus khilafah pada era kontemporer memiliki karakter yang khas, dimana tema-tema pembahasan seputar wajib tidaknya mendirikan khilafah, dan ada tidaknya system politik yang baku di dalam islam, dan apakah khilafah merupakan sistempolitik yang baku di

\footnotetext{
79 Irfan Ardiansyah, "Pergeseran Dari Sistem Khilafah Ke Nation State Dunia Islam”, UIR Law Review Volume 01, Nomor 02, Oktober 2017.

80 Irfan Ardiansyah, “Pergeseran Dari Sistem Khilafah Ke Nation State Dunia Islam”, UIR Law Review Volume 01, Nomor 02, Oktober 2017.

81 Irfan Ardiansyah, "Pergeseran Dari Sistem Khilafah Ke Nation State Dunia Islam”, UIR Law Review Volume 01, Nomor 02, Oktober 2017.
} 
dalam islam. Tema-tema dalam diskursus khilafah kontemporer terkait erat dengan situasi politik di dunia Islam dimana tidak adanya lagi kekhilafahan di dunia Islam, dihapuskanya kekhilafahn Turki Utsmani pada tahun $1924 \mathrm{M}$.

\section{Daftar Pustaka}

Al-Amin, Ainur Rofiq. Membongkar Proyek Khilafah Ala Hizbut Tahrir Indonesia. Yogjayakarta: LkiS, 2012.

Al-Banna. Hasan. Risalah Pergerakan al-Ikhwan al-Muslimun 1. Terj. Anis Matta dkk. Solo: Era Intermedia, 2006.

Al-Mawardi, Abu Hasan Ali bin Muhammad bin Habib. Al-Ahkam al-Sultaniyah. Ttp.: Haramain Jaya, t.t.

Al-Mawardi, Imam. Ahkam Sulthaniyah: System Pemerintahan Khilafah Islam, trj. Jakarta: Qisthi Press, 2014.

Al-Nawawi, Imam. Sahih Muslim bi al-Syarh An-Nawawi, penterj. Wawan Djunaedi Soffandi Terj. Syarah Shahih Muslim. Jakarta: Mustaqim, 2002.

Ardiansyah, Irfan. "Pergeseran Dari Sistem Khilafah Ke Nation State Dunia Islam”, UIR Law Review Volume 01, Nomor 02, Oktober 2017.

Ayubi, Nazih N. Political Islam; Religion and Politics in The Arab World. London: Ruotledge, 1991.

Azra, Azyumardi. "Sirah Nabi Muhammad Saw; Antara Historisitas dan Mitologi”, disampaikan pada diskusi peluncuran buku M. Quraish Shihab Mambaca Sirah Nabi Muhammad Saw dalam Sorotan al-Qur'an dan Hadits-Hadits Shahih, pada 23 Juli 20011 di hotel Sultan Jakarta.

Azra, Azyumardi. Pergolakan Politik Islam; dari Fundamentalisme, Modernisme Hingga Post-Modernisme. Jakarta: Paramadina, 1996.

Azra, Azyumardi. Pergolakan Politik Islam; dari Fundamentalisme, Modernisme Hingga Post-Modernisme. Jakarta: Paramadina, 1996.

Black, Antony. Pemikiran Politik Islam; dari Masa Nabi Hingga Masa Kini. Terj. Abdullah Ali dkk. Jakarta: Serambi Ilmu Semesta, 2006.

Black, Antony. Pemikiran Politik Islam; dari Masa Nabi Hingga Masa Kini. Terj. Abdullah Ali dkk. Jakarta: Serambi Ilmu Semesta, 2006.

Budiardjo, Miriam. Dasar-dasar Ilmu Politik. Jakarta: PT. Gramedia Pustaka Utama, 2010.

Budiardjo, Miriam. Dasar-Dasar Ilmu Politik. Jakarta: PT. Gramedia Pustaka Utama, 2008.

CNN Indonesia. "FPI, Khilafah Islamiyah dan Negara yang Lenyap", https://www.cnnindonesia.com/ nasional/20170815161722-20-234929/fpi-khilafah-islamiyah-dan-negara-yang-lenyap 13 / 08/ 2019.

Djazuli, A. Ilmu Fiqh: Penggalian, Perkembangan, dan Penerapan Hukum Islam. Jakarta: Kencana, 2005.

Gibtiah dan Yusida Fitriati. "Perubahan Sosial dan Pembaruan Hukum Islam Perspektif Sadd alDzari'ah”, Jurnal Nurani, Vol. 15, No. 2, Desember 2015, 101- 114.

Hitti, Philip K. History of Arabs. Jakarta: Zaman, 2018.

Intan, Tjut. "Saddudz Dzariah dan Permasalahanya (Sebuah Kajian Ushul Fiqh)”. Perpustakaan Digital UIN Sunan Kalijaga Yogyakarta., 2018. 
Iqbal, Muhammad. Fiqh Siyasah: Komtekstualisasi Doktrin Politik Islam. Jakarta: Prenadamedia Group, 2014.

Jamhari dan Jajang Jahroni. Gerakan Salafi di Indonesia. Jakarta: PT. Raja Grafindo Persada, 2004.

Kamil, Sukron. "Peta Pemikiran Politik Islam Modern dan Kontemporer" Jurnal Universitas Paramadina 3, no. 1, September (2003): 72.

Kemendikbud RI. Kamus Besar Bahasa Indonesia (KBBI) Daring, Badan Pengembangan Bahasa dan Perbukuan, Kemendikbud RI, 2012. https://kbbi.kemendikbud.go.id.

Mardani. Ushul Fiqh. Jakarta: Rajawali Pers, 2013.

Mubarok, Husni. “Ide Khilafah, ujian kita berdemokrasi”, https://geotimes.co.id/kolom/ide-khilafahujian-kita-berdemokrasi/. Diakses pada 17 September 2020.

Mujani, Saeful. Muslim Demokrat; Islam, Budaya Demokrasi, dan Partisipasi Politik di Indonesia Pasca Orde Baru. Jakarta: PT Gramedia Pustaka Utama, 2007.

Mulia, Musdah. Negara Islam Edisi Kedua. Depok: Kata Kita, 2010.

NU Online. "Menengok Kembali Makna Khilafah dan Khalifah”, Rabu 3 April 2019 10:30 WIB https:// www.nu.or.id/post/read/104352/menengok-kembali-makna-khilafah-dan-khalifah diakses pada $13 / 08 / 2019$.

NU Online. "Menengok Kembali Makna Khilafah dan Khalifah”, Rabu 3 April 2019 10:30 WIB https:// www.nu.or.id/post/read/104352/menengok-kembali-makna-khilafah-dan-khalifah diakses pada $13 / 08 / 2019$.

Prasetyo, Joko. "Gagasan Khilafah sampai di Bumi Sakura”, dalam Media Umat, edisi 56. April 2011.

Rahardjo, Mudjia. "mengenal ragam studi teks: dari content analysis hingga post-modernisme". https://www.uin-malang.ac.id. Diakses 14/08/2019.

Rahman, Fazlur. Major Themes of The Qur'an. Minneapolis: Bibliotica, 1989.

Rifa'i, Moh. Ushul Fiqh. Bandung: PT. Al-Ma'arif, 1995.

Saebani, Beni Ahmad. Fiqh Siyasah: Terminologi dan Lintas Sejarah Politik Islam Sejak Muhammad Saw, Hingga al-Khulafa'u al-Rasyidun. Bandung: Pustaka Setia, 2008.

Salim, Arskal. Challenging the Secular State: The Islamization of Law in Modern Indonesia. Honolulu: University of Hawai'i Press, 2008.

Sjadzali, Munawir. Islam dan Tata Negara: Ajaran, Sejarah, dan Pemikiran. Jakarta: UI Pres, 2008.

Syarif, Mujar Ibnu, dan Khamami Zada. Fiqh Siyasah: Doktrin Dan Pemikiran Politik Islam. Jakarta: Penerbit Erlangga, 2008.

Tempo. “8 Rekomendasi ijmtima' ulama PA 212, ada pulangkan rizieq shihab”. Tempo.co. 5 Agustus 2019, pukul 19:23 WIB

Wahid, Marzuki, dan Rumadi, Fiqh Madzhab Negara: Kritik Atas Politik Hukum Islam di Indonesia. Yogyakarta: LKiS, 2001.

Yatim, Badri. Sejarah Peradaban Islam. Jakarta: PT. Rajawali Pers, 2010.

Zein, Satria Effendi M. Ushul Figh. Jakarta: Kencana Prenadamedia Group, 2005. 
